\title{
Macrophytes of sacred Himalayan lake Dodi Tal, India: quantitative and diversity analysis
}

\begin{abstract}
The present study was conducted for quantitative and diversity analyses of aquatic macrophytes dwelling littoral zone of sacred lake Dodi Tal (3,075 masl) situated in Garhwal Himalaya in summer and winter seasons of 2015 and spring of 2016. A total of 45 macrophyte species belonging to 29 families and 34 genera were reported. These macrophytes varied in different morphological groups- emergents; submerged; rootedfloating leaf type; and free floating. Maximum number of species were represented by emergents (30) followed by submerged (10), rooted- floating leaf type (3) and free floating (3) macrophytes. Two emergent species (Renunculus letus, Myriophyllum verticillatum) of macrophytes dominated during all the three seasons. Renunculus letus was dominant in summer (IVI=10.40) and spring ( $I V I=12.61)$ seasons, while Myriophyllum verticillatum was dominant in winter season (IVI=12.94). The highest species diversity (H') of macrophytes was observed during summer (3.77) followed by spring (3.53) and winter (3.40) season. The abundant growth of aquatic macrophytes in the littoral zone of the lake may be due to various anthropogenic activities of the tourists in the riparian zone of the Dodi Tal. The huge growth of macrophytes during springs and summer seasons may be correlated with huge influx of tourists during this period.
\end{abstract}

Keywords: Garhwal himalaya, high altitude lake, importance value index (ivi), macrophytes, species diversity
Volume I Issue 4 - 2017

\author{
Sharma RC, Singh S \\ Department of Environmental Sciences, Hemvati Nandan \\ Bahughuna Garhwal University, India
}

\begin{abstract}
Correspondence: Ramesh C Sharma, Department of Environmental Sciences, Hemvati Nandan Bahughuna Garhwal University, Srinagar, Garhwal, 246174, Uttarakhand, India,
\end{abstract} Email drrameshcsharma@gmail.com Received: September 29, 2017 | Published: November 17,
2017

\section{Introduction}

Biodiversity is one of the most important characteristics of the aquatic ecosystem for maintaining its stability and resilience. ${ }^{1}$ Aquatic macrophytes are macroscopic forms of aquatic vegetation, including macroalgae, mosses, ferns and angiosperms found in aquatic habitat. They have evolved from many diverse groups and often demonstrate extreme flexibility in structure and morphology in relation to changing environmental conditions. ${ }^{2}$ Macrophytes of freshwater ecosystems have diverse roles to play in the structure and functioning of these ecosystems. ${ }^{3}$ Macrophytes are considered as an important component of the aquatic ecosystem not only as the habitat and food source for aquatic life, but also act as an efficient accumulator of heavy metals ${ }^{4-7}$ and as an important participant in the natural processes of water self-purification of water. ${ }^{8}$ Aquatic macrophytes represent the most important biotic component of the littoral zone of the lake ecosystem. ${ }^{9}$ Different forms of macrophytes exhibit seasonally variable growth patterns. ${ }^{3}$ Number of species and importance values of macrophytes, determines the species diversity of a community. ${ }^{10}$ Importance Value Index (IVI), a quantitative parameter, is useful, for providing the details on density and frequency of a species in relation to community. ${ }^{11}$ However, the species diversity is a useful index for the comparison of communities under the influence of anthropogenic disturbances. ${ }^{12}$

A considerable contribution on the aquatic macrophytes of India has been made. ${ }^{13-19}$ Although, some scattered reports are available on the lakes of Garhwal Himalaya. ${ }^{20,21}$ No sincere attempt has been made on the diversity and quantitative analyses of the macrophytes of the sacred Himalayan lake of Dodi Tal. The present study will be important for the conservation and management of the sacred lake through regulating the influx of the tourists to this Himalayan lake. As the quantity and diversity of macrophytes are the important parameters for assessing the health of the ecosystem.

\section{Materials and methods}

\section{Study area}

The Garhwal Himalaya is dotted with many high altitude lakes. The Dodi Tal is a very important high altitude sacred lake of the Garhwal Himalaya. The lake is dedicated to lord Ganesha (Dundi Maharaj), the most respected God of Indian mythology. The lake is known as the birth place of lord Ganesh, the younger son of lord Shiva. Therefore, it is worshiped by a large number of devotees. It is located between latitude $30^{\circ} 52^{\prime} 31.99 \mathrm{~N}$ and longitude $78^{\circ} 31^{\prime} 12.47^{\prime \prime} \mathrm{E}$ at an altitude of 3,075m a.s.1. in Uttarkashi district of Uttarakhand state, India. It is surrounded by dense oak (Quercus) forest and mountains at three sides. The lake is fed by two snow fed streams originated from an alpine meadow - Bakariya Khagi Pass (Figure 1). The only outlet of Dodi Tal partially forms the river Asi Ganga, an important tributary of Bhagirathi river. Dodi Tal is semi triangular in shape and measures $248.22 \mathrm{~m}$ long and $151.99 \mathrm{~m}$ wide at its broadest points. The littoral zone of this high altitude lake is very prominent. However, the littoral zone of this lake is very shallow at the water level fluctuates seasonally. Dodi Tal has a maximum depth of $19.97 \mathrm{~m}$ with an average depth of $9.98 \mathrm{~m}$.

The surrounding floristic environment of Dodi Tal is mainly represented by temperate vegetation. The upper zone is dominated by some common tree species like Pinus spp L., Quercus spp L., Rhododendron spp L., Abies pindrow Royle, Lyonia ovalifolia (Wallich) Drude, Alnus nepalensis D. Don, Cedrus deodara (Roxb. ex D. Don), Picea smithiana (wallich) Boissier and Taxus spp L., Acer spp L., Juglans regia L. , and Betula utilis D.Don. The beneath 
narrative is dominated by the shrubs like Berberis aristata DC., Salix elegans Wallich ex Anderson, Aconitum spp. L., Picrorhiza kurrooa Royle ex Benth , Nardostachys grandiflora DC and Dactylorhiza hatagirea D.Don along with some climbers like Clematis grata Wallich and Clematis gouriana Roxb. ex DC. The area also supports a good faunal diversity such as Himalayan Musk deer (Moschus chrysogaster Hodgson,), Himalayan tahr (Hemitragus jemlahicus C.H. Smith), Snow leopard (Panthera uncia Schreber,), Himalayan goral (Naemorhedus goral Hardwicke), Asiatic Black bear (Ursus thibetanus G. [Baron] Cuvier), Common leopard (Panthera pardus Linnaeus), Hanuman langur (Semnopithecus entellus Dufresne,) and Rhesus macaque (Macaca mulatta Zimmermann).

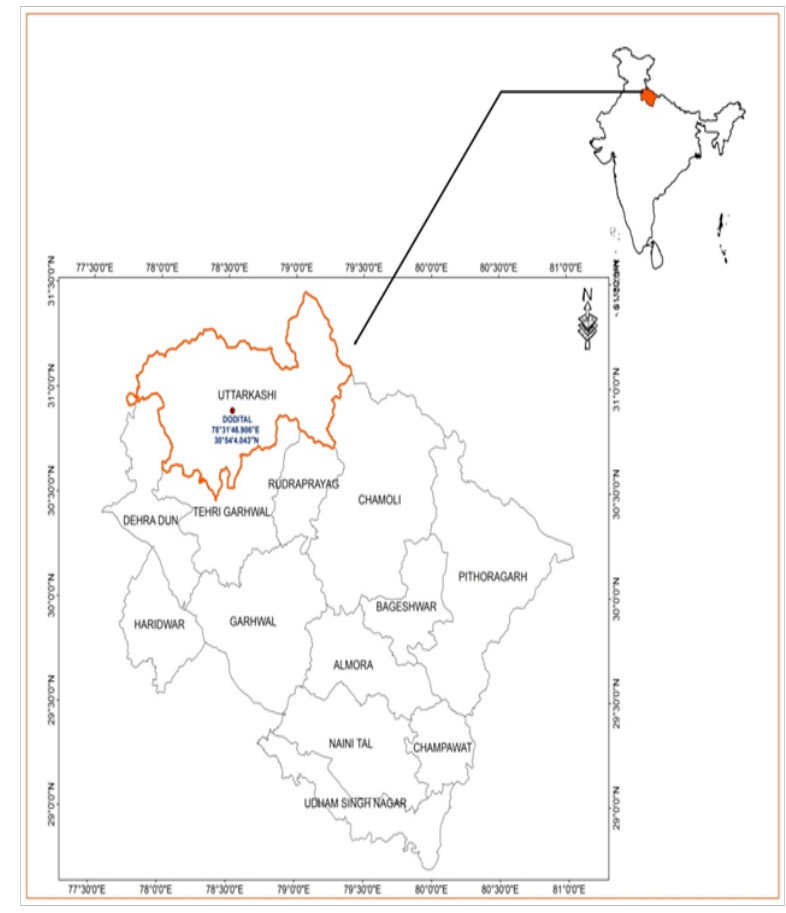

Figure I Location map of the study area, a sacred Himalayan lake, Dodi Tal.

\section{Macrophyte sampling}

Quantitative and diversity analyses of macrophytes of Dodi Tal was carried out in the littoral zone during summer (August 2015), winter (December 2015) and spring (May 2016) seasons. A random sampling along several transects with the help of a $1 \mathrm{~m}^{2}$ light wooden quadrat was undertaken. The quadrat size was determined by the species area curve method. ${ }^{22}$ The length of transect and numbers of quadrats in each transect within each sampling unit were adjusted according to the depth of the littoral zone. The centre of the Dodi Tal was not accessible for quadrat study due to its high depth. All the macrophytes were counted by hand picking. A total of 60 quadrats were studied during each season - 15 quadrats from each sampling sites. The plant species were identified with the help of standard literature ${ }^{23-31}$ and visual inspection by plant taxonomists.

Importance Value Index (IVI) was calculated by totaling the relative values of density, frequency and cover (by visual estimation). Diversity index (H') was calculated following the Shannon \& Weiner ${ }^{32}$ formula: $\mathrm{H}^{\prime}=-\Sigma \mathrm{pi}^{*} \log \mathrm{pi}$; where, $\mathrm{pi}=$ the proportion of importance value of the ith species, $\mathrm{pi}=\mathrm{ni} / \mathrm{N}$, ni is the importance value of $\mathrm{i}$-th species and $\mathrm{N}$ is the importance value of all the species. ${ }^{22}$ The Pielou's evenness index is also an important component of the diversity indices. Pielou's evenness $J=H^{\prime} \ln (S)$ is a measure of equitability, a measure of how evenly the individuals are distributed among the different species. Thus Pielou's Evenness ${ }^{33}$ commonly expressed by $J$ ' was also calculated.

\section{Results}

A total of 45 species of macrophytes belonging to 34 genera and 29 families were recorded from the littoral zone of the high altitude lake, Dodi Tal of Garhwal Himalaya (Table 1). These aquatic macrophytes are used by local people as food, fodder and medicinal purposes. Maximum number of species belonged to emergent (30 species) followed by submerged (10 species), rooted-floating leaf type ( 3 species) and free floating ( 3 species) macrophytes. The Cyperaceae family was found to be highly dominant in the emergent macrophytes. While no single family showed dominance in the free floating ones; whereas, the family Potamogetonaceae was found to be highly dominant in both submerged as well as rooted floating leaf types. Macrophytes dwelling the littoral zone of Dodi Tal and their common name, category of uses, have been presented in (Table 1). The composition of macrophytes in the littoral zone of the Dodi Tal is clearly visible in (Figure 2) (Figure 3).

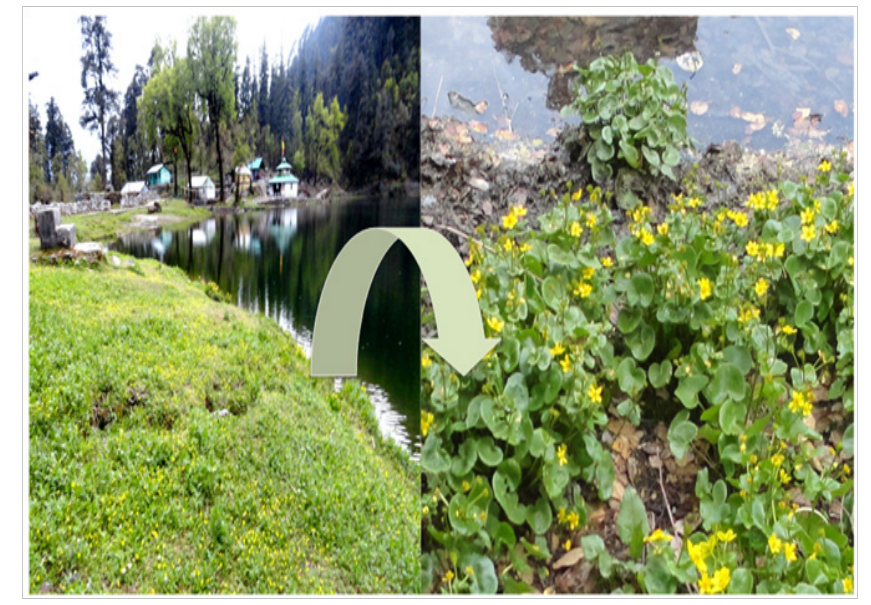

Figure 2 Macrophytes in Dodi Tal.

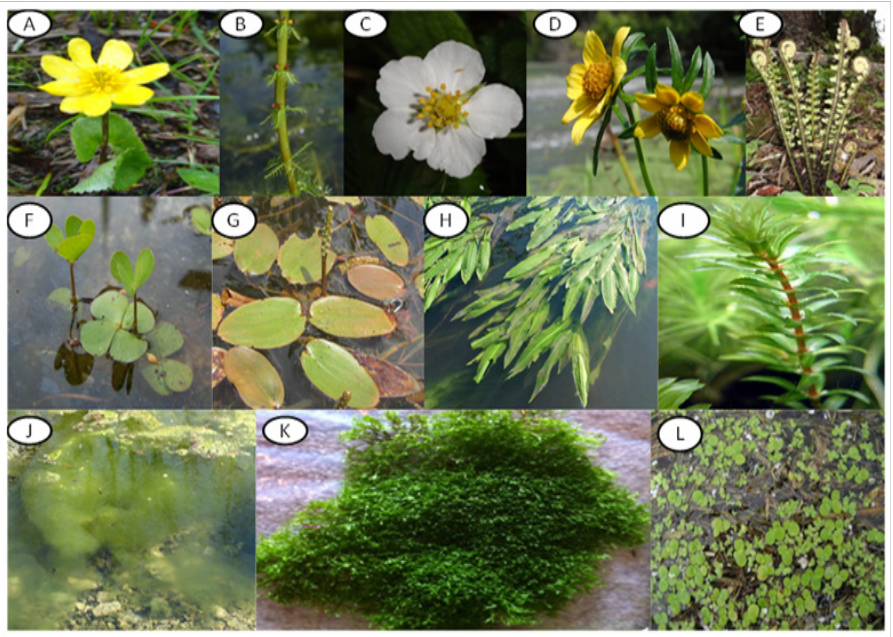

Figure 3 Macrophytes Composition of Dodi Tal, I. Emergent species A, Ranunculus letus; B, Myriophyllum verticillatum; C, Bidens Pilosa; D, Bidens cirnua; E, Dryopteris wallichiana; 2. Rooted - floating leaf type species F, Marsilea quadrifolia; G, Potamogeton natans; H, Potamogeton nadosus; 3.Submerged species I, Hydrilla verticillata; J, Chara spp. 4.Free floating K, Riccia fluitans; L, Lemna species. 
Table I Aquatic macrophytes (category, common name, family and uses) dwelling littoral zone of sacred Himalayan lake Dodi Tal

\begin{tabular}{|c|c|c|c|c|}
\hline $\begin{array}{l}\text { Category of } \\
\text { macrophytes }\end{array}$ & Species & Family & Common name & Uses \\
\hline \multirow[t]{29}{*}{ Emergents } & Bidens pilosa L. & Asteraceae & Black jack, spanish needle & Food or medicine \\
\hline & Bidens cernua $\mathrm{L}$. & Compositae & $\begin{array}{l}\text { Nodding bur - marigold } \\
\text { (sunflower) }\end{array}$ & Medicinal herb, Folk medicine, \\
\hline & Carex wallichiana Spreng. & Cyperaceae & Sedges - & Food, livestock hay \\
\hline & Caladium mariscus L. & Cyperaceae & Swamp sawgrass & Livestock hay \\
\hline & $\begin{array}{l}\text { Dryopteris wallichiana (Spreng.) } \\
\text { Hyl. }\end{array}$ & Dryopteridaceae & Alpine wood fern & Medicinal anthelmintic \\
\hline & $\begin{array}{l}\text { Dryopteris odontoloma (Moore) } \\
\text { C. Chr. }\end{array}$ & Dryopteridaceae & Wood fern & Medicinal anthelmintic \\
\hline & $\begin{array}{l}\text { Eleocharis uniglumis (Link) } \\
\text { Schult. }\end{array}$ & Cyperaceae & Slender spike rush & Food, livestock hay \\
\hline & $\begin{array}{l}\text { Eleocharis palustris (L.) Roem. } \\
\text { \& Schult. }\end{array}$ & Cyperaceae & Common spike rush & Food, livestock hay \\
\hline & Galium album Mill. & Rubiaceae & - & - \\
\hline & Hippuris vulgaris $\mathrm{L}$. & Hippuridaceae & Common mare's tail & $\begin{array}{l}\text { Herbal medicine, curing stomach } \\
\text { ulcers, soothing inflammation skin }\end{array}$ \\
\hline & Lycopus europas L. & Lamiaceae & Bugleweed, Gypsywort & $\begin{array}{l}\text { Medicinal , astringent, cosmetic, douche, } \\
\text { narcotic, refrigerant }\end{array}$ \\
\hline & Menyanthes trifoliate L. & Menyanthaceae & Bogbean, buckbean & Bitter and strong taste, schnapps \\
\hline & Myriophyllum verticillatum $\mathrm{L}$. & Haloragaceae & Whorled water- milfoil & Good water oxygenator \\
\hline & Nasturtium offcinale L. & Brassicaceae & watercress & $\begin{array}{l}\text { Edible, rich in vitamin k,vitamin c, } \\
\text { riboflavin, calcium, vitamin B6 }\end{array}$ \\
\hline & $\begin{array}{l}\text { Phargmites australis (Cav.) Trin. } \\
\text { ex Steud. }\end{array}$ & Poaceae & $\begin{array}{l}\text { Common reed beds, perennial } \\
\text { grass }\end{array}$ & Great wood structure, edible \\
\hline & Polygonum hydropiper (L.) Spach & Polygonaceae & Water pepper & Active ingredients, essential oil, edible \\
\hline & Ranunculus letus $\mathrm{L}$. & Ranunculaceae & Leaved buttercup & \\
\hline & Ranunculus secleratus $\mathrm{L}$. & Ranunculaceae & Celery - leaved buttercup & Blisters on human skin \\
\hline & Sagittaria sagittifolia L. & Alismataceae & Arrowhead & Tuber is edible, medicinal \\
\hline & Scirpus lacustris (L.) Palla & Cyperaceae & $\begin{array}{l}\text { Lakeshore bulrush, common club } \\
\text { rush }\end{array}$ & - \\
\hline & Scirpus triqueter (L.) Palla & Cyperaceae & Deergrass, grassweed & - \\
\hline & $\begin{array}{l}\text { Scirpus palustris (L.) Roem. \& } \\
\text { Schult. }\end{array}$ & Cyperaceae & Common spike - rush & - \\
\hline & Scirpus maritimus L. & Cyperaceae & Club- rush & - \\
\hline & Sium latijugum C. B. Cl. & Apiaceae & Large leaflet water parsnip & - \\
\hline & Sparganium erectum L. & Typhaceae & Branched bur reed & - \\
\hline & Sparganium ramosum Huds. & Sparganiceae & Bur reed & \\
\hline & Rumex maritimus Sm. & Polygonaceae & Golden dock & \\
\hline & Typha angustatifolia L. & Typhaceae & Reedmace, bulrush & Edible like flour \\
\hline & Veronica anagallis L. & Scrophulariaceae & Blue water speedwell & - \\
\hline \multirow[t]{2}{*}{$\begin{array}{l}\text { Rooted floating - } \\
\text { leaf type }\end{array}$} & Marsilea quadrifolia L. & Marsileaceae & Four leaf clover & $\begin{array}{l}\text { Edible, antiflammntory, treat snakebite } \\
\text { and applied abscesses }\end{array}$ \\
\hline & Potamogeton natans $\mathrm{L}$. & Potamogetonaceae & Broad - leaved pondweed & - \\
\hline
\end{tabular}


Table Continued...

\begin{tabular}{|c|c|c|c|c|}
\hline $\begin{array}{l}\text { Category of } \\
\text { macrophytes }\end{array}$ & Species & Family & Common name & Uses \\
\hline & Potamogeton nodosus Poir & Potamogetonaceae & Longleaf pondweed & - \\
\hline \multirow[t]{10}{*}{ Submerged } & Chara delicatula C.Agardh & Characeae & Green algae & Recreational use \\
\hline & Ceratophyllum demersum L. & Ceratophyllaceae & Hornwort, cootail & Popular aquarium plant, kill snails \\
\hline & Hydrilla verticillata (L.f.) Royle & Hydrocharitaceae & Hydrilla, waterthyme & Phytoremediation, Recreational use \\
\hline & Myriophyllum spicatum L. & Haloragaceae & Spiked water milfoil & - \\
\hline & Nitella spp. & Characeae & Green algae & - \\
\hline & Najas spp. & Hydrocharitaceae & Waternymphs, naiads & \\
\hline & Potamogeton crispus L. & Potamogetonaceae & $\begin{array}{l}\text { Curled pondweed or curly leaf } \\
\text { pondweed }\end{array}$ & - \\
\hline & Potamogeton lucens L. & Potamogetonaceae & Shining pondweed & - \\
\hline & Potamogeton pectinatus L. & Potamogetonaceae & & - \\
\hline & Ranunculus trichophyllus Chaix & Ranunculaceae & Threadleaf crowfoot & - \\
\hline \multirow[t]{3}{*}{ Free - floating } & Riccia fluitans $\mathrm{L}$. & Ricciaceae & Floating crystalwort & - \\
\hline & Lemna spp. & Lemnoideae & duckweed & Biopharmaceuticals \\
\hline & Salvinia natans (L.) All & Salviniaceae & Floating fern, floating moss & - \\
\hline
\end{tabular}

\section{Quantitative analysis of freshwater macrophytes}

The emergent macrophytes grow intensively in the littoral zone up to depth of $0.10-0.30 \mathrm{~m}$ except in the zones of flowing water (close to the outlet). The dominant ones among the emergent group were Myriophyllum verticillatum, Ranunculus letus, Sium latijugam, Sparganium erectum, Galium hartifolium and Sagittaria sagittifolia. The second layer is formed by the rooted floating - leaf type upto a depth of 0.30-0.50 m with predominance of Potamogeton nodosus, Potamogeton natans, Marsilea quadrifolia and Potamogeton crispus. The dominant submerged macrophytes growing abundantly in the limnetic zone include Chara spp., Hydrilla verticillata, Najas spp. Nitella spp. and Potamogeton crispus. The number of aquatic macrophyte species were higher during summer (45) and spring (35) seasons and low during winter (31) season (Table 2). The percentage composition of different forms of macrophytes is presented in (Figure 4). Emergent species contributed $(65 \%)$ to the total macrophytes, followed by submerged (22\%), free floating $(7 \%)$ and Rooted floating leave type (6\%) (Figure 4).

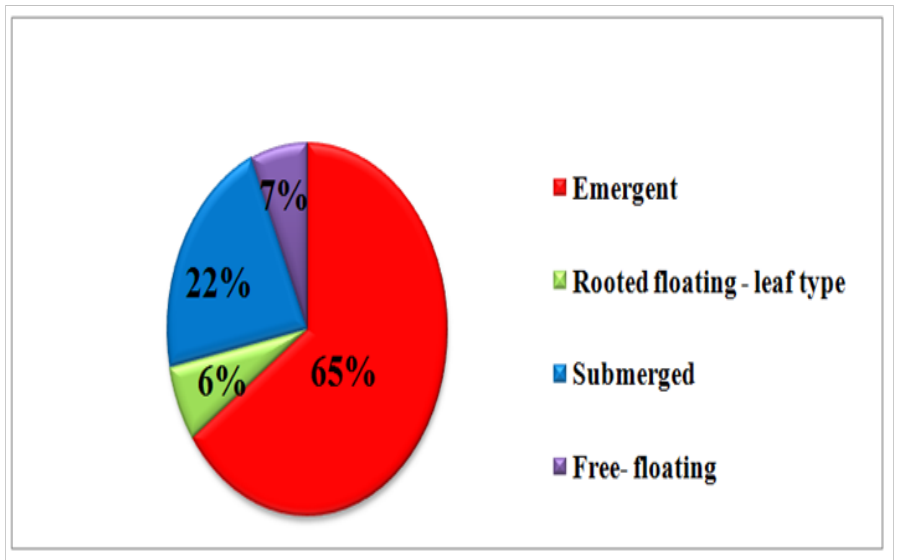

Figure 4 Percentage composition of different growth forms of macrophytes.
Table 2 Seasonal variations in important value index (IVI) of different growth forms of macrophytes of Dodi Tal

\begin{tabular}{|c|c|c|c|c|}
\hline \multirow{2}{*}{$\begin{array}{l}\text { Species, } \\
\text { categorized by } \\
\text { growth form } \\
\text { Emergent }\end{array}$} & \multicolumn{4}{|c|}{$\begin{array}{l}\text { Importance value index (IVI) } \\
\text { in }\end{array}$} \\
\hline & Summer & Winter & Spring & Average \\
\hline Bidens pilosa & 9.5 & 8.9 & 7.22 & 8.54 \\
\hline Bidens cernua & 9.6 & 0 & 9.44 & 6.35 \\
\hline Carex wallichiana & 7.4 & 0 & 6.46 & 4.62 \\
\hline Caladium mariscus & 8.6 & 8.7 & 5.11 & 7.47 \\
\hline Dryopteris wallichiana & 6.7 & 9.66 & 9.61 & 8.66 \\
\hline Dryopteris odontoloma & 7.4 & 9.79 & 8.45 & 8.55 \\
\hline Eleocharis uniglumis & 7.2 & 9.24 & 0 & 5.48 \\
\hline Eleocharis palustris & 5.9 & 9.64 & 0 & 5.18 \\
\hline Galium hertifolium & 6.1 & 0 & $1 \mathrm{l} .47$ & 5.86 \\
\hline Hippuris vulgaris & 6.2 & 11.05 & 8.45 & 8.57 \\
\hline Lycopus europas & 5.6 & 8.42 & 7.27 & 7.1 \\
\hline Menyanthes trifoliate & 5.8 & 0 & 8.15 & 4.65 \\
\hline $\begin{array}{l}\text { Myriophyllum } \\
\text { verticillatum }\end{array}$ & 7.3 & 12.94 & 6.98 & 9.07 \\
\hline Nasturtium offcinale & 6.5 & 0 & 8.24 & 4.91 \\
\hline Persicaria amphibia & 5.9 & 10.36 & 0 & 5.42 \\
\hline Phargmites australis & 5.1 & 0 & 0 & 1.7 \\
\hline Polygonum hydropiper & 5.4 & 0 & 0 & 1.8 \\
\hline
\end{tabular}


Table Continued..

\begin{tabular}{|c|c|c|c|c|}
\hline \multirow{2}{*}{$\begin{array}{l}\text { Species, } \\
\text { categorized by } \\
\text { growth form } \\
\text { Emergent }\end{array}$} & \multicolumn{4}{|c|}{$\begin{array}{l}\text { Importance value index (IVI) } \\
\text { in }\end{array}$} \\
\hline & Summer & Winter & Spring & Average \\
\hline Ranunculus letus & 10.4 & 0 & $|2.6|$ & 7.67 \\
\hline Ranunculus secleratus & 5.6 & 0 & 7.76 & 4.45 \\
\hline Sagittaria sagittifolia & 7.2 & 0 & 11.33 & 6.18 \\
\hline Scirpus lacustris & 7.8 & 4 & 0 & 3.93 \\
\hline Scirpus triqueter & 3.8 & 0 & 0 & 1.27 \\
\hline Scirpus palustris & 8.5 & 9.99 & 0 & 6.16 \\
\hline Scirpus maritimus & 4.5 & 8.92 & 0 & 4.47 \\
\hline Sium latijugum & 5.9 & II.7 & 9.16 & 8.92 \\
\hline Sparganium erectum & 5.9 & 11.52 & 7.59 & 8.34 \\
\hline Sparganium ramosum & 4.7 & 6.47 & 0 & 3.72 \\
\hline Rumex maritimus & 7.5 & 10.67 & 9.16 & 9.11 \\
\hline Typha angustatifolia & 4.7 & 5.01 & 0 & 3.24 \\
\hline Veronica anagallis & 3.5 & 0 & 6.88 & 3.46 \\
\hline Total & 196.2 & 166.98 & 161.34 & I 74.84 \\
\hline \multicolumn{5}{|c|}{ Rooted Floating - Leaf Type } \\
\hline Marsilea quadrifolia & 8.1 & 0 & 9.63 & 5.91 \\
\hline Potamogeton natans & 6 & 11.7 & 9.16 & 8.95 \\
\hline Potamogeton nodosus & 6.8 & 12.04 & 8.03 & 8.96 \\
\hline Total & 20.9 & 23.74 & 26.82 & 23.82 \\
\hline \multicolumn{5}{|l|}{ Submerged } \\
\hline Chara delicatula & 9.7 & 12.7 & 11.02 & 11.14 \\
\hline $\begin{array}{l}\text { Ceratophyllum } \\
\text { demersum }\end{array}$ & 7.8 & 6.58 & 7.87 & 7.42 \\
\hline Hydrilla verticillata & 8.2 & 12.04 & 10.4 & 10.2 \\
\hline Myriophyllum spicatum & 6.9 & 9.76 & 7.51 & 8.06 \\
\hline Nitella spp. & 7.4 & 10.58 & 9.63 & 9.2 \\
\hline Najas spp. & 4.5 & 10.7 & 7.22 & 7.47 \\
\hline Potamogeton crispus & 7.6 & 10.23 & 8.89 & 8.91 \\
\hline Potamogeton lucens & 7.7 & 9.66 & 7.37 & 8.24 \\
\hline Potamogeton pectinatus & 0 & 9.76 & 6.39 & 5.38 \\
\hline $\begin{array}{l}\text { Ranunculus } \\
\text { trichophyllus }\end{array}$ & 5.8 & 0 & II.II & 5.64 \\
\hline Total & 65.6 & 92.01 & 87.41 & 81.67 \\
\hline \multicolumn{5}{|l|}{ Free - floating } \\
\hline Riccia fluitans & 5 & 6.31 & 8.46 & 6.59 \\
\hline
\end{tabular}

$\begin{array}{lllll}\text { Lemna spp. } & 7.2 & 10.93 & 6.78 & 8.3 \\ \text { Salvinia natans } & 5.5 & 0 & 9.26 & 4.92 \\ \text { Total } & \mathbf{1 7 . 7} & \mathbf{1 7 . 2 4} & \mathbf{2 4 . 5} & \mathbf{1 9 . 8 ~ I} \\ \text { Grand total } & \mathbf{3 0 0 . 4} & \mathbf{2 9 9 . 9 7} & \mathbf{3 0 0} & \mathbf{3 0 0 . 1}\end{array}$

\section{Importance value index (IVI) of freshwater macrophy-} tes

The dominance of species by growth forms on the basis of IVI value is presented in (Table 2). Emergents were the most dominant form throughout the year. The emergent macrophytes grow intensively in the littoral zone except near the outlet region. Seasonally, IVI of emergent macrophytes was highest in the summer, followed by spring and winter seasons. Among emergents, Renuculus letus, Bidens pilosa, Bidens cirnua and Galium hertifolia were the most dominant in the summer and the spring seasons, and Myriophyllum verticillatum, in the winter season. After emergents, the next highest IVI values were those of submerged species in the winter and spring, followed by rooted floating - leaf type species in the winter and spring. Among the emergent species, Myriophyllum verticillatum was highly dominant throughout the year. The highest IVI values for this species were found in the winter (12.94), followed by the summer (7.30) and the spring season (6.98). Among the submerged species, Chara delicatula was highly dominant. The maximum IVI values for this species were recorded in the winter (12.70), followed by the spring (11.30) and the summer season (9.70). Consequently, the lowest IVI value for Chara delicatula was observed during the summer. Among the submerged species, Chara delicatula (IVI: 12.70) Hydrilla verticillata (IVI: 12.04) and Najas spp. (IVI: 10.70) were recorded to be the most dominant species throughout the year. Chara delicatula indicates its ability to adapt in miscellaneous conditions throughout the year. Among the growth forms, floating-leaved species were the least dominant in terms of average IVI value (19.81). The high growth of rooted floating-leaved species, especially Potamogeton nodosus was observed during the winter and spring seasons in this wetland. Annual average IVI values of emergent's were found to be dominant (174.84), followed by the submerged (81.67), rooted floating-leaved species (23.82) and free-floating (19.81) macrophytes.

Statistical differences in the values of Importance value index (IVI) of macrophytes between seasons was also tested using ANOVA test. The difference between the seasons were found statically insignificant (one way ANOVA, emergents $\mathrm{F}=0.750, \mathrm{P}=0.475$, rooted floating - leaf type $\mathrm{F}=0.179, \mathrm{P}=0.839$, submerged $\mathrm{F}=2.56, \mathrm{P}=0.095$, free floating $\mathrm{F}=0.500, \mathrm{P}=0.629)$.

\section{Shannon-Weiner's diversity index of freshwater ma- crophytes}

The computation of Shannon-Weiner diversity index ( $\left.\mathrm{H}^{\prime}\right)$ of macrophytes revealed that the species diversity was highest for emergents (2.48) in summer followed by the submerged, rooted floating leaf type and free-floating species respectively (Table 3). The highest species diversity for the entire community was found in the summer (3.77), as compared to 3.53 in the spring and 3.40 in the winter. The average value for the community as a whole was found to be $3.57 \pm 0.15$. Also, in a particular season, the diversity of different growth forms varied (Table 3) (Figure 5). For example, in summer season, the highest diversity was found for emergents (2.48) followed by submerged $(0.80)$, rooted floating-leaf type $(0.26)$ and free floating $(0.23)$. The variation of diversity among different growth forms with 
respect to seasons and contribution of growth forms to diversity in different seasons is shown diagrammatically in (Figure 5). The highest species diversity index (3.77) for the entire community was found in the summer, as compared to the winter (3.40) and the spring (3.53). Thus, it has been revealed that there is a definite indication of significant seasonal change in the macrophytic community of the littoral zone of the Dodi Tal.

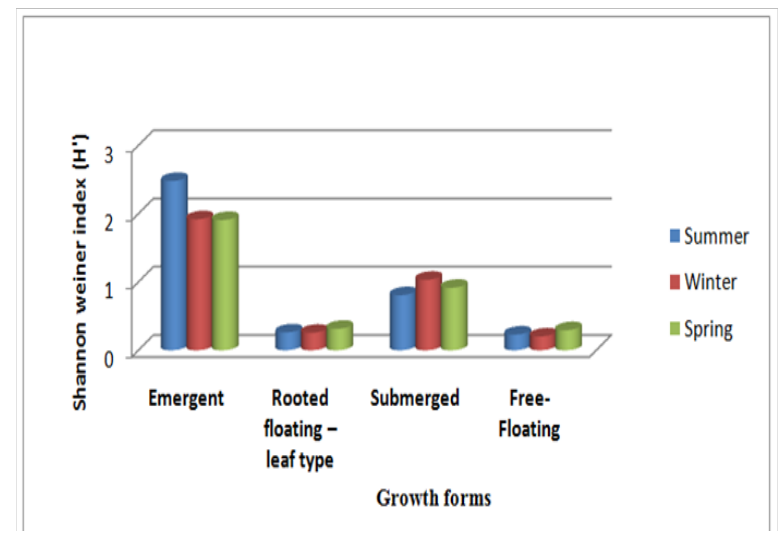

Figure 5 Seasonal variation in Shannon Weiner diversity index $\left(\mathrm{H}^{\prime}\right)$ in different growth forms (emergent, rooted, submerged and free floating) macrophytes dwelling Dodi Tal.

Table 3 Seasonal variations in Shannon Weiner species diversity index ( $\left.\mathrm{H}^{\prime}\right)$ value in different growth forms of macrophytes of Dodi Tal.

\begin{tabular}{|c|c|c|c|c|}
\hline \multirow[t]{3}{*}{$\begin{array}{l}\text { Growth forms } \\
\text { of species }\end{array}$} & \multicolumn{4}{|c|}{$\begin{array}{l}\text { Shannon - weiner' index of species } \\
\text { diversity }(H)\end{array}$} \\
\hline & \multirow[b]{2}{*}{ Summer } & \multirow[b]{2}{*}{ Winter } & \multirow[b]{2}{*}{ Spring } & $\overline{\mathrm{X}}_{ \pm S D}$ \\
\hline & & & & \\
\hline Emergent & 2.48 & 1.919 & 1.908 & $2.102 \pm 0.27$ \\
\hline $\begin{array}{l}\text { Rooted - } \\
\text { floating leaf type }\end{array}$ & 0.261 & 0.256 & 0.314 & $0.277 \pm 0.03$ \\
\hline Submerged & 0.807 & 1.032 & 0.915 & $0.918 \pm 0.09$ \\
\hline Free - Floating & 0.23 & 0.202 & 0.294 & $0.242 \pm 0.04$ \\
\hline $\begin{array}{l}\text { Total } \\
\text { community } \\
\text { value (Dodi Tal) }\end{array}$ & 3.779 & 3.408 & 3.537 & $3.575 \pm 0.15$ \\
\hline
\end{tabular}

\section{Pielou's Evenness index of freshwater macrophytes}

The data on Pielou's evenness calculated for macrophytes dwelling in Dodi Tal have been presented in Table 4. It was found to be maximum $\left(\mathrm{J}^{\prime}=0.9949\right)$ in spring season and minimum $\left(\mathrm{J}^{\prime}=0.9927\right)$ in winter season with highest species number $(S=45)$ recorded in summer season. Pielou's evenness index response depends on the manner in which the community changes. In this context evenness in Dodi Tal, there was no considerable change in the community of all the sampling sites.

Table 4 Seasonal variations in Pielou's Evenness index (J') calculated for macrophytes of Dodi Tal

\begin{tabular}{llll}
\hline Season & \multicolumn{3}{c}{ Pielou's evenness index (J') } \\
\cline { 2 - 4 } & S & H' $^{\prime}$ & J' \\
\hline Summer & 45 & 3.779 & 0.9929 \\
Winter & 31 & 3.408 & 0.9927 \\
Springs & 35 & 3.537 & 0.9949 \\
\hline
\end{tabular}

S, Species Number; H', Shannon-Wiener Index; J', Pielou's Evenness

\section{Discussion}

The quantitative seasonal analysis of the macrophytic composition of the littoral zone of the high altitude lake may provide baseline information for formulating conservation and management strategies for this high altitude lake of Garhwal Himalaya. The quantity and diversity of macrophytes are the important parameters for assessing the health of the ecosystem. Influx of tourists can be regulated in different seasons for managing the integrity of the ecosystem. Reduction in the growth of macrophytes can be minimized it will improve the health of the ecosystem.

Emergent were the most dominant form throughout the year on the basis of IVI value. Myriophyllum verticillatum was highly dominant throughout the year. The highest IVI values for this species was found in the winter (12.94), followed by the summer (7.30) and the spring season (6.98). Higher growth of Myriophyllum verticillatum in the winter than in the summer may be due to sedimentation, snow melting, and human interference (highly nutrient enrichment present in inlet site 1 of this lake. The increasing abundance of emergents covering extensive areas in lake littoral zone of the wetland may be due to water level fluctuations accompanied with decreasing depth and nutrient enrichment mainly by allochthonous material by the way of sedimentation. ${ }^{34}$ This water milfoil species, Myriophyllum verticillatum is a good water oxygenator and also ideal in providing protection and respiration for fish spawn. Natural competition with other invasive aquatic plants has been the main control. So, we found that this species is very important for the purification of high altitude lake, Dodi Tal. This can be attributed to the emergent high tolerance for fluctuation of water level. ${ }^{35}$

After emergents, the next highest IVI values were those of submerged species in the winter and spring, followed by rooted floating - leaf type species in the winter and spring seasons. Among the submerged species, Chara delicatula was highly dominant. The high IVI values for this species were recorded in the winter (12.70), followed by the spring (11.30) and the summer season (9.70). During the summer, Chara delicatula was found to flow with water from the wetland due to seasonally high water levels and snow melting water including improper sanitation around the wetland. Consequently, the lowest IVI value for Chara delicatula was observed during the summer. No record of Chara delicatula has been found in high altitude lakes of The Himalayas. Its current dominance may be attributed to its invasive nature and also its preference for highly disturbed and stagnant water at temple site. Chara delicatula is found growing in the very clean and hard water lakes. Sometimes called musk grass, because they give off a musky or shunk- like odour. It is also a wetland indicator. The dynamic year-round growth of Chara delicatula indicates its ability to adapt in miscellaneous conditions. Crawfish (freshwater crustaceans) herbivory may select against perennial macrophytes and promote growth of pioneering plants like Chara. ${ }^{36}$ The factors like biotic interferences through local and tourist influx of nutrient rich run off not only affect the diversity of macrophytic species growing in these lakes, but also the entire biodiversity of the lacustrine ecosystem. ${ }^{14}$

The silt load and mixing of allochthonous material in the Dodi Tal were due to continuous landslides and runoff carrying a considerable silt, organic matter and litter from the catchment area. The dense growth of Hydrilla verticillata in the winter season can be attributed to the high growth potential of this species in sedimentation prone areas site 1 (inlet) of Dodi Tal. Sediment slope and texture also influence growth, distribution and occurrence of the macrophytes species is a particular water body. ${ }^{37,38}$ The dense growth of rooted floating-leaved species, especially Potamogeton nodosus in the winter and spring 
seasons, may be attributed to better adaptability of the rooted floatingleaved species to the stresses of water level fluctuations, to the tearing action of water turbulence, and to turbidity of water. ${ }^{39}$ Some species occurred across a wide range of lake plant richness, whereas, some species appeared to be good indicators of high richness like rooted floating - leaf type. ${ }^{40}$ The dense growth of free-floating and rooted floating-leaved species prevented colonization of submerged species in the summer and the winter seasons. ${ }^{41}$ Free floating macrophytes with significant dominant species, Lemna sp. and Salvinia natans. Lemna spp. are well known for its high productivity in littoral zones and high protein content in temperate climates. ${ }^{42}$

On the basis of annual average IVI values, it was found that emergents were dominant (174.84), followed by the submerged (81.67), rooted floating-leaved species (23.82) and free-floating (19.81) in Dodi Tal. Species diversity was highest for the emergents (2.480) in summer followed by the submerged, rooted floating leaf type and free-floating species respectively. The same seasonal trend was reported by Van der Valk \& Davis ${ }^{34}$ and Handoo \& Kaul ${ }^{43}$ in their studies. Species diversity is a useful parameter for the comparison of communities under the influence of biotic disturbance or to know the state of succession and stability in the community. ${ }^{44}$ The seasonal variations in miscellaneous growth forms may cause the variations in the species diversity. The diversity index ( $\left.\mathrm{H}^{\prime}\right)$ for macrophyte ranged from 3.40-3.77 in Dodi Tal. These are comparable with those reported by Burlakoti et al. ${ }^{2}$ (3.17-4.17) in Beeshazar, Chitwan, Nepal; Sharma ${ }^{14}$ (0.51-1.50) in Jammu and Kashmir, India; Sarmah et al. ${ }^{12}$ (2.51-3.21) in Monrikhaboloobeel wetland of river Subansiri, Assam; Sharma et al. ${ }^{44}$ (2.70-1.77), India and Biswas et al. ${ }^{45}$ (2.300.86) Chhariganga oxbow lake in Nadia district, West Bengal, India. All these studies have been conducted in different parts of Asia.

The present quantitative analysis of macrophytes shows a definite indication of significant changes in the macrophytic community of the Dodi Tal. The most significant change in macrophytic community may be due to heavy siltation in the catchment area of the lake is due to frequent landslides at the tourist's activities depending on their influx in different seasons. The silt raising the lake thick layer brings in large quantities of nutrients in to the lake. In oligotrophic and mesotrophic lakes, nutrient loading increases tolerant aquatic macrophyte species abundance. ${ }^{46}$ Another reason for increasing sedimentation is the climatic change due to global warming ensuing in increased melting of glaciers, there by bringing in more and more sediments into the lake as the main source of water to the lake is neighboring glaciers. ${ }^{34}$

\section{Conclusion}

The abundant growth of the macrophytes in the littoral zone of the Dodi Tal wetland reveals the dynamic nature of the wetland. The dominance of emergents among other growth forms (as shown by IVI dimensions) indicates the disturbance caused by the various anthropogenic activities of the tourists in the riparian zone of the wetland. Based on the above results, it can be concluded that the high altitude wetland, Dodi Tal, showed high diversity of macrophytes during summer season. The obtained Shannon-Weaver diversity index value $\left(H^{\prime}=3.57\right)$ indicates rich species diversity in Dodi Tal lake. The dominance of Chara delicatula indicates its invasive nature of this macrophytes. The fact that emergents have the highest species diversity and lowest free floating species signifies the increasing richness in species with decreasing water level. Therefore, it is suggested that Chara delicatula should be removed immediately from this high altitude wetland ecosystem, so that it should not further deteriote the health of the ecosystem. For overall conservation and management of this high altitude wetland, the influx of tourists should be regulated in various seasons for minimizing and arresting the growth of the macrophytes, consequently imporving the health of the Dodi Tal. ${ }^{47}$

\section{Acknowledgements}

One of the authors (Sushma Singh) is thankful to the University Grants Commission, New Delhi and H.N.B Garhwal University (A Central University) Srinagar - Gharwal, Uttarakhand for providing her fellowship during the period of study.

\section{Conflict of interest}

The authors declare that there is no conflict of interests to declare regarding the publication of this paper.

\section{References}

1. Singh N, Sharma RC. Some important attributes which regulates the life of macro-invertebrates: a review. International Journal of Recent Scientific Research. 2014;5(2):357-361.

2. Burlakoti C, Karmacharya SB. Quantitative analysis of macrophytes of Beeshazar Tal, Chitwan, Nepal. Himalayan Journal of Sciences. 2004;2(3):37-41.

3. Wetzel RG. Limnology. Academic Press, San Diego, USA; 2001.

4. Devlin RM. Plant Physiology. Reinhold, New York; 1967.

5. Chung IH, Jeng SS. Heavy metal pollution of Ta-Tu River. Bulletin of the Institute of Zoology, Academy of Science. 1974;13:69-73.

6. Acharya P. Wetland vegetation and its utilization in Ghodaghodi and Nakhrodi Tal, Kailali,. PhD thesis, Kathmandu, Nepal; 1997.

7. Scheffer M. Alternative stable states in eutrophic freshwater systems: A minimal model. Hydrobiological Bulletin. 1989;23:73-83.

8. Dembitsky VM, Rezanka T, Bychek IA. Fatty acid and phospholipids from lichens of the order Leconorales. Phytochemistry. 1992;31:851-853.

9. Piecznyska E. Littoral habitats and communities. In: Jorgensen SE, Loeffler H, editors. Guidelines of Lake Management. International Lake Environment Committee and UNEP. Japan; 1990.

10. Odum EP. Fundamentals of ecology. 3rd ed. Nataraj Publishers, Dehra Dun, India; 1996.

11. Curtis JT, McIntosh RP. An upland forest continuum in the prairie forest border region of Wisconsin. Ecology. 1951;32:476-98.

12. Sarmah BP, Baruah D. Quantitative analysis of macrophytes of Morikhaboloo beel (Wetland) of River Subansiri, Assam. Der Pharmacia Lettre. 2015;7(9):209-214.

13. Purohit R. Phytosociological productivity and growth behavior of potamogeton pectinatus in relation to physico-chemical limnology of the lake Nainital, India. Nainital, India; 1981.

14. Sharma S. Macrophytic diversity and state of environment of three lakes of Jammu province. Proceeding of Taal 2007: the 12th World lake Conference. 2008. p. 2081-2087.

15. Singh, KK, Sharma BM. Ecological productivity studies of the macrophytes in Kharungpat Lake, Manipur northeast India. International Journal of Geology, Earth and Environmental Sciences. 2012;2(2):58-71.

16. Kanue PSA, Munsi S, Zubair SM, et al. Water chemistry of hazratbal Basin of Dal Lake in Kashmir. J Life Sciences Leaflets. 2013;3:89-95.

17. Saikia M. Aquatic macrophytes of the wetlands of Hojai sub division, Nagaon district of Assam, India. J Global Journal of Biology, Agriculture and Health Science. 2013;2(3):141-145. 
18. Bimal R, Akhtar N, Anand A, et al. Systematic enumeration of aquatic vascular plants of Muzaffarpur with special reference to B.R.A. Bihar University Campus. J Indian Journal of Advances in Plant Research. 2014;1(6):14-16.

19. Odelu G. Present status of aquatic macrophytes of four fresh water ecosystems of ellandhakuta and its surrounding villages, Karim nagar district, Telangana. India. J Biolife. 2014;2(3):956-965.

20. Sharma RC, Kumar K. Conservation and management of lakes of Garhwal, Himalaya. In: Kumar, editor. Ecology and conservation of lakes, reservoir and rivers. ABD publishers, Jaipur, India; 2002. p. 562-580.

21. Agarwal AK, Rajwar GS. Macrophytes of Tehri Dam Reservoir, Garhwal Himalaya, India. The Asian and Australasian Journal of Plant Science and Biotechnology. 2010;4(1):81-85.

22. Zobel DB, Jha PK, Yadav UK, et al. A practical manual for ecology. Kathmandu, Nepal; 1987.

23. Sculthorpe CD. The biology of aquatic vascular plants. Edward Arnold, London; 1967.

24. Jain SK, Rau RR. A Hand book of field and herbarium methods. Today and Tomorrow Printers and Publishers. New Delhi, India; 1976.

25. Khan MS, Halim M. Aquatic angiosperms of Bangladesh. Bangladesh National Herbarium, Bangladesh; 1987.

26. Cook CDK. Aquatic and wetland plants of India. Oxford University Press, New York; 1996.

27. Gurung VL. Ferns: The Beauty of Nepalese Flora. Sahayogi Press Pvt Ltd, Kathmandu, Nepal; 1991.

28. Fassett NC. A Manual of Aquatic plants. Agrobios, Jodhpur, India; 1998.

29. Gaur RD. Flora of the district Garhwal, North West Himalaya. Transmedia, Garhwal, Srinagar, India; 1999. p. 844.

30. Press JR, Shrestha KK, Sutton DA. An annotated checklist of flowering plants of Nepal. British Museum of Nature History, London, UK; 2000.

31. Munshi DJS, Roy SP. Manual of freshwater biota. Narendra Publishing House, New Delhi, India; 2010.

32. Shannon CE, Weiner W. The mathematical theory of communication. University of Illinois Press, Urbana, USA; 1964. p. 1-132.

33. Pielou EC. The measurement of diversity in different type of biological collection. Journal of theoretical biology. 1966;13:131-44.

34. Wani SA, Pandit AK. Ecological distribution and floristic diversity change in nilang, a high altitude Himalayan lake under threat. Proceeding of Taal 2007: the 12th World lake Conference, 2008. p. 430-434.
35. Vander Valk AG, Davis CB. Changes in the composition, structure and production of plant communities along a perturbed wetland coenocline. Vegetation. 1976;32(2):87-96.

36. Rosenthal SK, Stevens SS, Lodge DM. Whole-lake effects of invasive crayfish (Orconectes sp.) and the potential for restoration. Canadian Journal of Fisheries and Aquatic Sciences. 2006;63(6):1276-1285.

37. Pearshall WH. The aquatic vegetation of the English lakes. Journal of Ecology. 1920;8(3):163-201.

38. Spence DHN. Factors controlling the distribution of freshwater macrophytes with special reference to the lochs of Scotland. J Ecol. 1967;55:147-149.

39. Papastergiadou E, Babalonas D. Ecological studies on aquatic macrophytes of Dam Lake: Lake Kerkini, Greece. Arch Hydrobiol Suppl. 1992;90(2):187-206.

40. Radomski P, Perleberg D. Application of a versatile aquatic macrophyte integrity index for Minnesota lakes. Ecological Indicators. 2012;20:252-268.

41. Kaul V, Trisal CL, Handoo JK. Distribution and production of macrophytes of some aquatic bodies of Kashmir. In: Singh JS, Gopal B, editors. Glimpses of Ecology. International Scientific Publications Jaipur, Jaipur, India; 1978. p. 313-334.

42. Sharma P, Dwivedi HS. Diversity of Aquatic Macrophytes of Govardhan Sagar water body at Ujjain (M.P.) India. International Journal of Advanced Research in Biological Sciences. 2016;3(8):89-93.

43. Handoo JK, Kaul V. Phytosociological and crop studies in wetlands of Kashmir. In: Gopal B, Turner RE, editors. Wetland ecology and management. International Scientific Publications, Jaipur, India; 1982.

44. Sharma SK, Deka U. Quantitative analysis of macrophytes and physico-chemical properties of water of two wetlands of Nalbari district of Assam, India. Scholars Research Library, Annals of Biological Research. 2014;5(5):77-84.

45. Biswas KJ, Ghosh D. Biomonitoring macrophytes diversity and Abundance for rating aquatic health of an oxbow lake ecosystem in Ganga River Basin. American Journal of Phytomedicine and Clinical Therapeutics. 2015;3(10):602-621.

46. Garrison PJ, Wakeman RS. Use of paleolimnology to document the effect of lake shore development on water quality. Journal of Paleolimnology. 2000;24(4):369-393.

47. Chambers PA, Lacoul EP, Murphy E, et al. Global diversity of aquatic macrophytes in freshwater. Hydrobiologia. 2008;595:9-26. 